\title{
Речевые стратегии американского предвыборного дискурса на примере речи
}

\section{Д. Трампа}

\author{
Николаева С.В., студентка, \\ Северо-Восточный федеральный университет, \\ 2. Якутск \\ E-mail: nikolsara@yandex.ru
}

Научный руководитель: к.ф.н., доцент Федорова К.И.

Предвыборная кампания в США получила широкое освещение разнообразными СМИ. В рамках данной статьи мы хотим проанализировать речевое поведение Д. Трампа и выделить используемые им стратегии и тактики предвыборного политического дискурса.

Для начала остановимся на определении предвыборного политического дискурса. Багана Ж., Бочарова Э.А. трактуют его как жанр политического дискурса, который существует в форме совокупности текстов, включающих в себя агитационные материалы какой-либо предвыборной кампании, распространяемые в определенный промежуток времени [1, стр. 124].

Предвыборный политический дискурс, как и всякий дискурс, имеющий целью воздействие на адресата, учитывает систему взглядов и ценностей аудитории, чтобы изменить намерения, контролировать действия и повлиять на мнение. По словам В.З. Демьянкова, политик в своей речи оперирует символами, которые предназначены «затрагивать нужные струны» в массовом сознании [2, стр. 35].

Поэтому речь политика представляет собой произведение, заранее подготовленный текст с использованием разнообразных приемов и техник для воздействия на избирателей. Средствами достижения мотивов говорящего выступают речевые стратегии и тактики, обусловленные установками говорящего, системами его ценностей и убеждений.

Рассмотрим, каким образом в речи Д. Трампа осуществляется использование коммуникативных стратегий и тактик.

Одной из основных задач политической коммуникации является получение преимущества перед соперником. Такие стратегии, как самопрезентация и дискредитация наиболее эффективно способствуют этой цели. Стратегия дискредитации, в свою очередь, осуществляется путем использований тактик обвинения, насмешки и оскорбления [3, стр. 105]. Так, в своей речи [5] Д. Трамп имеет целью обвинение своих политических оппонентов Б. Обамы и Х. Клинтон. Например:

«Our foreign policy is a complete and total disaster. No vision, no purpose, no direction, no strategy» [5]. /Наша внешняя политика это полная катастрофа. Нет ни видения, ни цели, ни направления, ни стратегии.

«President Obama has weakened our military by weakening our economy. He's crippled us with wasteful spending, massive debt, low growth, a huge trade deficit and open borders» [5]. / Президент Обама ослабил нашу военную мощь тем, что он ослабил экономику. Он искалечил нас пустыми тратами, огромной задолженностью, медленным развитием, гигантским торговым дефицитом и открытыми границами. 
В представленных фрагментах мы видим, как реализуется тактика обвинения в предвыборной речи Д. Трампа. С самого начала своего выступления, политик приводит характеристику состояния, в котором находится страна (complete and total disaster) и винит действующего на тот момент президента Обаму (President Obama has weakened, He’s crippled us). Использование лексически окрашенного слова “сripple” усиливает негативное отношение к объекту обвинения.

Несомненно, субъект, осуществляющий речевое воздействие, хочет выглядеть в хорошем свете в глазах аудитории. Для этой цели эффективным приемом является стратегия самопрезентации, выражающаяся тактикой оппозиционирования. Здесь использована базовая оппозиция «свой-чужой», которая разграничивает «свой» круг лиц от «чужих». В данном случае, политик подчеркивает расхождение своих интересов и, в том числе, интересов народа, страны с политикой президента (President Obama, our military, our economy, Не’s crippled us). Идентификация говорящего с народом вводится с помощью личных местоимений “our”, “us”. Тем самым, используя тактику отождествления, говорящий сближает себя со слушающими и, следовательно, облегчает коммуникацию с ними.

Дискредитация оппонента достигается также и путем насмешек:

«After Secretary Clinton's failed intervention in Libya, Islamic terrorists in Benghazi took down our consulate and killed our ambassador and three brave Americans. Then, instead of taking charge that night, Hillary Clinton decided to go home and sleep! Incredible.» [5].

После неудавшегося вмешательства госсекретаря Клинтона в Ливии исламские террористы в Бенгази захватили наше консульство и убили нашего посла и троих отважных американцев. Тогда вместо того, чтобы брать на себя ответственность за ту ночь, Хиллари Клинтон решила пойти домой и поспать! Невероятно.

Далее в речи Д. Трампа приводятся минусы существующей внешней политики, которые разделены на пять пунктов. Такое перечисление является примером использования тактики констатации проблемы, после которого, как правило, следует тактика указания на путь решения проблемы. Приведем примеры:

«One day we're bombing Libya and getting rid of a dictator to foster democracy for civilians, the next day we are watching the same civilians suffer while that country falls apart» [5]. / В один день мы бомбим Ливию и избавляемся от диктатора, чтобы принести демократию мирным жителям, а на следующий день мы наблюдаем за тем, как те же граждане страдают, пока их страна разваливается (тактика констатации проблемы)

«We should work together with any nation in the region that is threatened by the rise of radical Islam» [5]. / Мы должны сотрудничать с любой страной, которой угрожает рост радикального ислама (тактика указания на путь решения проблемы)

Так как одной из основных задач предвыборного политического дискурса является убеждение избирателей в необходимости совершения «политически правильных» действий [1, стр. 124], в данной речи говорящий предлагает выбрать себя, единственно подходящего кандидата, в качестве нового президента:

«A Trump Administration will lead a free world» [5]. / Администрация Трампа будет вести к свободному миру.

«I will view the world through the clear lens of American interests. I will be America’s greatest defender and most loyal champion» [5]. / Я буду смотреть на мир сквозь призму американских интересов. Я стану величайшим защитником Америки и его самым верным сторонником. 
«I am the only person running for the Presidency who understands this problem and knows how to fix it» [5]. / Я единственный человек, из числа кандидатов на пост президента, который понимает эту проблему и знает, как ее решить.

Реализуется тактика обещаний, которая выражается добровольным обязательством сделать что-либо [4, стр. 174]. Для реализации данной тактики использована форма будущего времени совершенного залога (will lead, I will view, I will be), которая вводит уверенность в выполнении обещанного.

Коммуникативная цель говорящего ясна - убедить избирателей в том, что именно он является достойным кандидатом в президенты.

Параллельно с тактикой обещаний реализуется и тактика единения с избирателями при помощи использования местоимений “we”:

«We will always help to save lives and, indeed, humanity itself. But to play that role, we must make America strong again. We must make America respected again. And we must make America great again» [5]. / Мы всегда будем помогать спасать жизни и само человечество. Но чтобы исполнять эту роль, мы должны снова сделать Америку сильной. Мы должны снова сделать Америку уважаемой. И мы должны снова сделать Америку великой.

В приведённом выше примере удачно использованы различные стилистические приёмы: параллельные конструкции (strong again, respected again. great again), градация (strong-respected-great) что делает речь ритмичной, эмоциональной, выразительной.

Таким образом, успешное сочетание речевых стратегий и тактик в предвыборном политическом дискурсе позволяет политику привлечь на свою сторону огромное количество избирателей.

\section{Список литературы:}

1. Багана Жером, Бочарова Эмилия Александровна Предвыборный политический дискурс как особая сфера коммуникации // Вестник РУДН. Серия: Лингвистика. 2012. №1 С.121-125.

2. Демьянков В.3. Политический дискурс как предмет политологической филологии // Политическая наука. Политический дискурс: История и современные исследования. № 3. - М., 2002. - с.32-43.

3. Иссерс О.С. Коммуникативные стратегии и тактики русской речи. Изд. 5-е. /О.С. Иссерс - М.: Издательство ЛКИ, 2008. - 288 с.

4. Паршина О.Н. Стратегии и тактики речевого поведения современной политической элиты России: Дисс. ... доктора филол. наук./ О.Н. Паршина. - Саратов, 2005. - c. 331.

5. Donald J. Trump. Foreign Policy Speech [Электронный pecypc]. URL: https://www.donaldjtrump.com/press-releases/donald-j.-trump-foreign-policy-speech (дата обращения: 13.03.17). 